\title{
Spatial Variability of Irrigated Garlic (Allium sativum L.) Production Components
}

\author{
Job Teixeira de Oliveira, Rubens Alves de Oliveira, \\ and Lucas Allan Almeida Oliveira \\ Federal University of Viçosa, Viçosa, 8560-090, Brazil \\ Paulo Teodoro \\ Universidade Federal de Mato Grosso do Sul, Chapadão do Sul, 75560-000, \\ Brazil
}

\author{
Rafael Montanari \\ State University of São Paulo, Ilha Solteira, 15385-000, Brazil
}

Additional index words. precision agriculture, geostatistics, plant traits

\begin{abstract}
Among the crops that are usually grown under irrigation, one can mention garlic, which is a product with high demand in Brazil and the world, it is highly valued in the cuisine of several countries, and is an aggregated crop with high economic value. In 2018, this work was conducted in Yellow Red Latosol. The objective was to characterize the structure and magnitude of the spatial distribution of garlic production components and to map the productive components to visualize spatial distribution and to evaluate the spatial correlation between garlic bulb yield (BY) and other variables of the crop: total plant mass (TPM), number of leaves (NL), floral tassel length (FTL), leaf length (LL), leaf width (LW), pseudostem diameter (PD), shoot wet mass (SWM), shoot dry mass (SDM), number of cloves per bulb (NCB), clove mass (CM), root dry mass (RDM), and irrigation (IRR). All these traits were sampled in a 90point grid georeferenced. Data analysis using statistical and geostatistical techniques made it possible to verify that the production components and BY, TPM, NL, FTL, LL, LW, PD, SWM, SDM, CM, and IRR presented special dependence. The spatial correlation between $B Y$ and TPM, $L W$, and $C M$ showed a moderate spatial dependence.
\end{abstract}

Garlic (Allium sativum L.) is grown in practically the entire national territory and is recognized as an excellent source of proteins, vitamins, minerals, and fibers that nourish and reduce the incidence of diseases, besides being a food component of the Brazilian diet. In 2017, the total area of garlic grown in Brazil was 11130 ha with a production of 79.72 million tons, obtaining an average BY of 7.0 $\mathrm{Mg} \cdot \mathrm{ha}^{-1}$ [Instituto Brasileiro de Geografia e Estatística (IBGE), 2018].

Among the crops that are usually grown under irrigation, one can mention garlic, which is a product with high demand in Brazil and the world, it is highly valued in the cuisine of several countries, and is an aggregated crop with high economic value.

With the advent of precision agriculture in Brazil, the geostatistical study of crop production components related to crop yield has intensified (Oliveira et al., 2018). Ferraz et al.

Received for publication 24 July 2019. Accepted for publication 14 Aug. 2019.

Published online 24 January 2020.

P.T. is the corresponding author. E-mail: eduteodoro@ hotmail.com.

This is an open access article distributed under the $\mathrm{CC}$ BY-NC-ND license (https://creativecommons. org/licenses/by-nc-nd/4.0/).
(2012) defined precision agriculture as a set of techniques and technologies capable of assisting the farmers to manage their crops, aiming to increase production and income, as well as improving the efficiency in fertilization, harvesting, and spraying techniques, contributing, therefore, to improve the final quality of the marketed product.

In the scope of geostatistics, the study of the technique helps the computational programs used in precision agriculture; that is, data generated and adjusted from simple data interpolation (kriging) and cross-interpolation (cokriging) between plant traits vs. any other characteristic serve as a basis for estimating the spatial variability of a particular variable by means of another easily measured (Montanari et al., 2015).

Recently, Viana et al. (2016) studied the productive components of garlic to understand how to increase its productivity. However, these authors did not use geostatistics to verify whether these variables have spatial dependence. The objective of this work was to characterize the structure and magnitude of the spatial distribution of the production components of the garlic field and to map these production components to visualize the spatial distribution and to evaluate the spatial correlation between the garlic BY and the other morphoagronomic traits of the crop.
The study was developed in the irrigation and drainage area of the Federal University of Viçosa, in Viçosa, Minas Gerais State, Brazil, under the geographic coordinates: $23 \mathrm{~K}$, $722,569.09 \mathrm{~m} \mathrm{E} ; 7,701,897.59 \mathrm{~m} \mathrm{~S}$ (UTM) (Supplemental Fig. 1). According to Köppen and Geiger, the climate is classified as Cwa, with an average annual temperature of $20.6^{\circ} \mathrm{C}$. The summers have a high rainfall rate, and the average annual rainfall is $1230 \mathrm{~mm}$.

The soil in which the experimental grids were installed was a deep sandy soil, classified as Yellow Red Latosol (Empresa Brasileira de Pesquisa Agropecuária, 2018) with $46 \%$ of sand, $15 \%$ of silt, and $39 \%$ of clay in the depth of 0.0 to $0.2 \mathrm{~m}$. The $\mathrm{pH}$ in $\mathrm{H}_{2} \mathrm{O}$ was 6.0 and the organic matter content of $2.2 \mathrm{dag} \cdot \mathrm{kg}^{-1}$. The values of base sum and cation exchange capacity were 3.7 and $6.1 \mathrm{cmol}_{\mathrm{c}} \cdot \mathrm{dm}^{-3}$, respectively.

The experimental area was conducted under conventional tillage system and has a drip irrigation system. Before starting the experiment, the soil was plowed and harrowed to a depth of $0.30 \mathrm{~m}$ and then raised beds were made with the aid of a rotating hoe for the planting of garlic. The field soil was prepared on 1 May 2018, and on 7 May 2018, the planting of the purple garlic cultivar was carried out. Each sampling point was constituted by a site with $1.60 \mathrm{~m}$ of width and $1.60 \mathrm{~m}$ of length, totaling an area of $2.56 \mathrm{~m}^{2}$, being three double rows of garlic and the useful area composed of the middle row, disregarding the lateral rows and $0.30 \mathrm{~m}$ of each edge (Supplemental Fig. 2). The spacing between the double rows was $0.40 \mathrm{~m}$ and $0.10 \mathrm{~m}$ between the rows of the double row (Marouelli et al., 2014).

The $x$ and $y$ directions of the cartesian coordinate system were defined and, at the end of the garlic phenological cycle (15 Sept. 2018), the experimental grid was staked in plots spaced at $1.60 \mathrm{~m}$ between them. Each experimental grid consisted of three transects of $48.00 \times 1.60 \mathrm{~m}$. Therefore, the transects were spaced $1.60 \mathrm{~m}$, with sample points squared in $1.60 \times 1.60 \mathrm{~m}$, containing 90 of them.

The production components were individually determined in the useful area of the sampling point, which was composed of a double row with $1 \mathrm{~m}$ of length, totaling 20 plants. The morphoagronomic traits were measured between Oct. and Nov. 2018.

Garlic BY was determined by weighing all harvested bulbs and values expressed in $\mathrm{kg} \cdot \mathrm{ha}^{-1}$. The TPM (in grams) was determined by weighing the entire garlic plant after drying in the shade for $30 \mathrm{~d}$ after harvest. The NL corresponds to the number of leaves contained in a garlic plant. The FTL (in cm) refers to the length of the basal plate (bulb base) up to the apex of the umbel (floral bud). The LL (in $\mathrm{cm}$ ) refers to the length of the basal plate (bulb base) to the apex of the last leaf of the garlic plant. The LW (in mm) was measured in the central part of the last leaf of the garlic plant using a caliper. The PD (in $\mathrm{mm}$ ) was measured in the false stem at $5 \mathrm{~cm}$ 
above the garlic bulb with the aid of a caliper. The SWM (in grams) refers to weighing the shoot mass of the garlic plants at $30 \mathrm{~d}$ after harvest and exposed to drying in the shade. The SDM (in grams) was measured after oven drying at $105{ }^{\circ} \mathrm{C}$ for $72 \mathrm{~h}$. The NCB was determined by counting the garlic cloves of each bulb. The CM (in grams) was determined by weighing all cloves using a precision scale. The RDM (in grams) refers to the weight of the roots at $30 \mathrm{~d}$ after harvest exposed to drying in the shade. IRR with restriction applied to the bulb formation was determined by measuring the amount of water applied during the entire crop cycle, expressed in millimeters.

For all the morphological and agronomic traits of the garlic plants, the descriptive analysis was carried out using the statistical software Rbio (biometrics in R), version 17 (UFV, Viçosa, Brazil). The average, median, minimum and maximum values, standard deviation, the $\mathrm{CV}$, kurtosis, and asymmetry were calculated. Frequency distribution analysis was also performed. Thus, the test of Shapiro and Wilk (1965) at 5\% of significance was used to test the hypothesis of normality or lognormality of the production components $(x)$. In this statistical test, it was possible to test the null hypothesis, which is thought to be the sample coming from a population with the normal distribution.

To characterize the structure and magnitude of the spatial dependence of the (Fig. 1) components, semivariogram adjustments and semivariance estimation were performed, estimating the coefficients of the theoretical model for the semivariogram called the nugget effect $\left(\mathrm{C}_{0}\right)$, sill $\left(\mathrm{C}_{0}+\mathrm{C}\right)$, and the range $\left(\mathrm{A}_{0}\right)$. After the semivariograms were adjusted, the data were interpolated by kriging to allow the visualization of the spatial distribution patterns of the garlic production components, through maps. Standard error maps of kriging prediction were generated. Cross-validation is a tool to evaluate alternative models of simple and crossed semivariograms, which will perform kriging and cokriging, respectively. In its analysis, each point contained within the spatial domain is removed individually, its value is estimated as if it did not exist. In this way, a graph of estimated vs. observed values can be constructed for all points.

\section{Results and Discussion}

Data from the descriptive analysis of the garlic crop production components are shown in Supplemental Table 1. From the analysis of the average, minimum and maximum values, and also the variance of the values of the garlic production components, it can consider that the variability of the data are considerable. However, only the knowledge of this variation is not enough to identify the locations of the high values of a crop characteristic, nor the locations where the lowest values are found. In this case, the use of geostatistics becomes necessary to identify if there is spatial variability and how this variability occurs in the study area, with the consequent preparation of maps, to allow more precise management of the necessary field interventions.

According to Pimentel-Gomes and Garcia (2002), the variability of a characteristic can be classified according to the magnitude of its $\mathrm{CV}$. Their classes were determined as low ( $\mathrm{CV}$ $<10 \%)$, medium $(10 \%<\mathrm{CV}<20 \%)$, high $(20 \%<\mathrm{CV}<30 \%)$, and very high $(\mathrm{CV}>30 \%)$. Therefore, all indices varied from low to medium, BY, TPM, FTL, LL, PD, NCB, and $\mathrm{CM}$ presented low variability. The other production components NL, LW, SWM, SDM, RDM, and external component interference of the IRR presented a mean CV. Viana et al. (2016) found low coefficients of variation for the garlic morphological traits that corroborate with the present study for $\mathrm{NL}, \mathrm{LL}, \mathrm{LW}$, and $\mathrm{PD}$, being $5.03 \%, 4.21 \%, 7.60 \%$, and $9.51 \%$, respectively; however, the classification of the $\mathrm{CV}$ for BY (15.82\%) and NCB (21.57\%) differed according to their average and high scores. The average to low variability rates found for garlic production components can be explained by the fact that the studied soil is rich in nutrients, thus standardizing the $\mathrm{CV}$ of the garlic crop production components.

The study of the production components presented coefficients of positive asymmetry for TPM, NL, FTL, LL, LW, PD, and SWM, which were respectively $0.05 ; 0.02,0.30$, $0.20,0.43,0.18$, and 0.06 and negative for BY, SWM, NCB, CM, RDM, and IRR which were $-0.10,-0.10,-0.40,-0.11,-0.08$, and -1.34 , respectively (Supplemental Table 1). The coefficients of positive kurtosis for TPM, FTL, NCB, RDM, and IRR were 0.07; 0.34, $0.30,0.82$, and 1.05 , respectively. The production components BY, TPM, NL, FTL, LL, PD, SWM, SDM, NCB, CM and RDM were significant at $5 \%$ probability by the normality test of Shapiro and Wilk (1965), because their respective probabilities were of $0.6587 ; 0.6919 ; 0.6683,0.7137,0.8068$, $0.9815,0.4264 ; 0.7159,0.0956,0.6641$, and 0.0923 . Similar results for the grain yield and stem diameter in the study with common beans obtained normal frequency distribution (Oliveira et al., 2018). Montanari et al. (2013) found the frequency distribution of the type tending to normal for brachiaria dry matter.

The average BY of garlic was 10,321 $\mathrm{kg} \cdot \mathrm{ha}^{-1}$, being within the values found in garlic irrigated with high technology. The average bulb yield of the garlic crop in Brazil in 2017 was $7162 \mathrm{~kg} \cdot \mathrm{ha}^{-1}$ (IBGE, 2018).

The geostatistical analysis (Table 1, Supplemental Fig. 3) showed that there was spatial dependence for the semivariograms of the production components FTL, LW, and IRR, which fit the spherical model, whereas BY, TPM, NL, and SDM fit the exponential model, agreeing with Montanari et al. (2013), who say that spherical and exponential models present themselves as the most common theorists of soil and plant properties. However, the production components LL, PD, SWM, and CM conformed to the gaussian model. The production components NCB and RDM obtained pure nugget effect.

By the classification of Cambardella et al. (1994), semivariograms that have a nugget effect $<25 \%$ of the sill, moderate when it is between $25 \%$ and $75 \%$, and weak $>75 \%$, are considered as a strong spatial dependence evaluation (SDE). According to this classification, the values of the TPM, NL, and SDM variables presented strong SDE, whereas BY, TPM, LL, LW, PD, SWM, CM, and IRR presented moderate SDE.

The range values for semivariograms are of considerable importance in determining the spatial dependence limit (Supplemental Fig. 3), which also may be indicative of the interval between soil mapping units (Trangmar et al. 1985), and also of the production components related to crops (Oliveira et al., 2018). The range found by the variables ranged from $4.0 \mathrm{~m}$ (PD) to $25.0 \mathrm{~m}$ (CM). To support research in this area, it is suggested that the values of the ranges to be used in the geostatistics that will feed the computational packages used in precision agriculture, in general, should not be less than $4.0 \mathrm{~m}$.

After adjustments of the semivariograms for each production component of the garlic crop, values were estimated using ordinary kriging. In this way, it was possible to construct spatial distribution maps for all the variables of this study (except for NCB and RDM, which had pure nugget effect), which allowed visualization of the spatial variability in the area.

When analyzing the map of spatial variability of BY, we could see that the southern regions of the area presented the lowest yields of the crop. The highest values of productivity were observed in the northern region of the area. The observation of a productivity map (Fig. 1A), together with the observation of other types of maps, such as those of crop production components, can contribute to find reasons for the occurrence of BY variability, especially in the case of low yield, which will make it possible to correct the failures, allowing in the next harvest to minimize these problems. In this way, the farmer can take advantage of the historical information from the area from previous mappings to make the decisions necessary for the good progress of the crop. Identifying regions that have a greater or lesser need for intervention are in the soil or the crop (Oliveira et al., 2018).

These maps also can be used in the management of the harvest, as they will contribute to the estimation of yield, logistics, and choice of the point of garlic cure in the shed, which can help in a better yield of the product for commercialization. Observing the spatial distribution map of the TPM (Fig. 1B), it can be seen that a large part of the central area is classified as low weight. This indicative is essential for the producer because the mass is directly proportional to the bulb size (maintaining uniformity in crop moisture) and reflects in the classification of the bulb separation screen. The mass of standardized garlic plants 

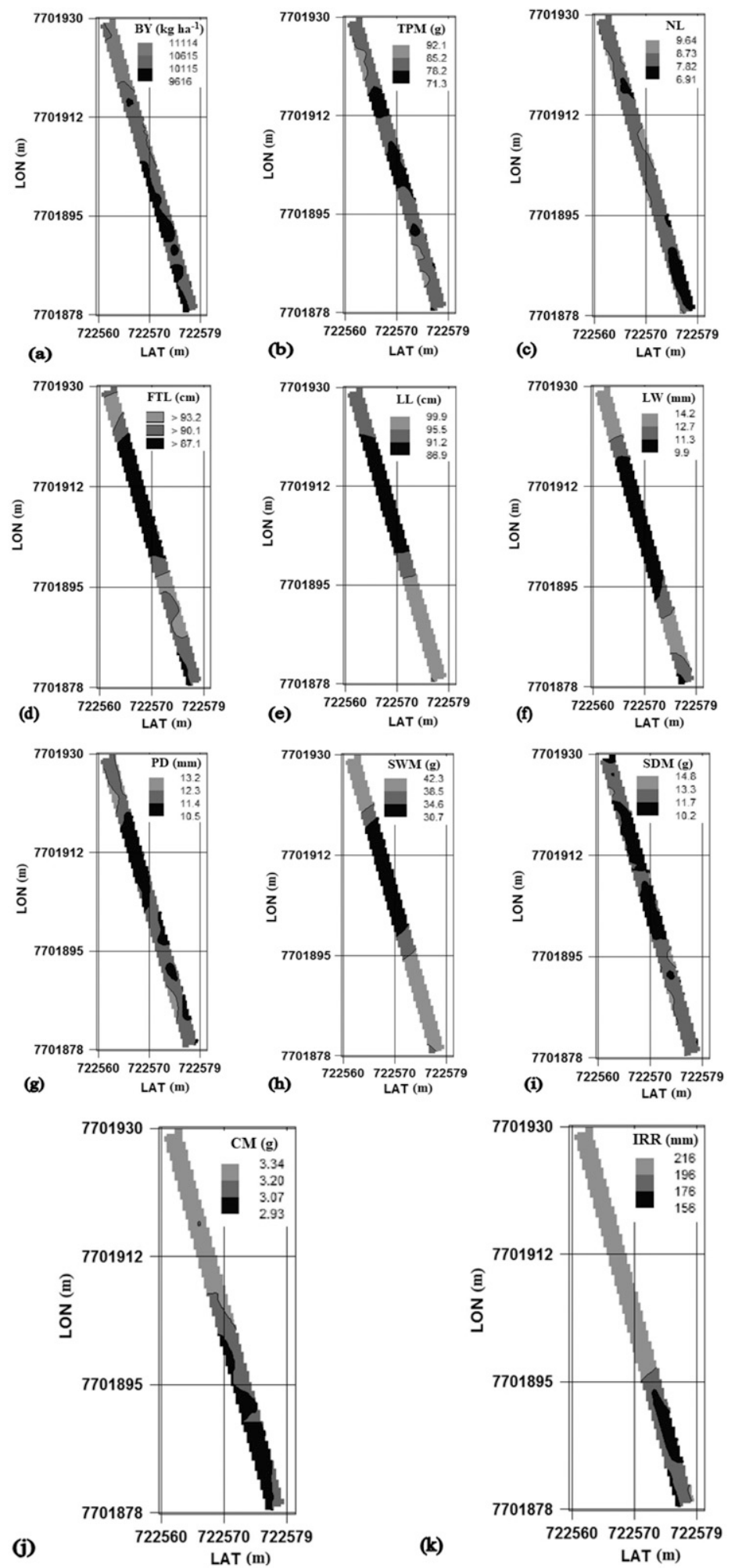

Fig. 1. Simple kriging maps of the garlic production components: (A) garlic bulb yield (BY), (B) total plant mass (TPM), (C) number of leaves (NL), (D) floral tassel length (FTL), (E) leaf length (LL), (F) leaf width (LW), (G) pseudostem diameter (PD), (H) shoot wet mass (SWM), (I) shoot dry mass (SDM), (J) clove mass (CM), and (K) irrigation (IRR), with restriction applied in the bulb formation ( $\mathrm{mm}$ ). $\mathrm{LAT}=$ latitude; $\mathrm{LON}=$ longitude.

is more commercialized and, mainly, it makes possible a greater separation of the bulbs by weight obtaining standardization of yield.

The NL per plant classified (Fig. 1C) provides evidence that the southern region of the area presented the lowest counts. LL and LW were found to be smaller in the central parts of the study area. These indicatives reflect on the photosynthesis rate performed by the plant because smaller sizes, widths, and leaf quantities imply the reduction of light absorption (Brewster, 2008).

The FTL was measured in a smaller dimension in the center of the area, as well as for the PD (Fig. 1G). The differentiation of the inflorescence after induction at low temperature is favored, with its growth at relatively low temperatures and short photoperiods (e.g., below $13{ }^{\circ} \mathrm{C}$ and $12 \mathrm{~h}$ ). These conditions cause a slow onset of inflorescence and onset, but they delay the formation of bulbs more than the formation of inflorescences (Brewster, 2008).

The SWM and SDM (Figs. $1 \mathrm{H}$ and I, respectively) in the southern portion of the map obtained the largest masses. The other regions varied between medium and low dry matter production. The amount of this attribute studied can help in the preparation of garlic string, because a greater amount of dry matter assists in support of the string.

The CM is an important characteristic that indicates its development and contributes to commercialization. This characteristic is closely related to the management imposed on the crop. In this way, the identification of the spatial variability of this phenological index and its consequent mapping can collaborate with the producers in the identification of distortions that are occurring in the field to enable its correction. The highest CM values could be observed in the northern portion (Fig. 1J) and the lowest values identified in the south. Bessa et al. (2017) described that the percentage of empty cloves of garlic (without mass) or index of empty cloves are among the most serious defects pointed out by ministerial ordinances, with $15 \%$ being the maximum allowed as a limit for the batch to be considered of the commercial type. The ordinance n. 242/92 of the Ministry of Agriculture provides that, to belong to the noble garlic group, garlic must have, among other characteristics, not more than 20 cloves per bulb. The consumer garlic market prefers bulbs of larger size and with a small NCB, an important fact for commercialization, when bulbs with these characteristics reach the highest prices (Resende, 1997).

When the cross-semivariogram was performed between the production components of garlic crop, positive spatial correlations (Table 2 ) for BY $=f(T P M), B Y=f(L W)$ and $\mathrm{BY}=\mathrm{f}(\mathrm{CM})$ there was moderate spatial dependence $(\mathrm{SDE}=59.8 \%, 35.4 \%$, and $33.3 \%$, respectively), and with spherical adjusted model for $B Y=f(L W)$ and gaussian model for $B Y=f(T P M)$ and $B Y=f(C M)$. These results show a direct relationship between BY and the studied production components, i.e., taking the $\mathrm{CM}$ as an example, there is an increase in yield. Oliveira et al. (2018) found in the cokriging of bean yield as a function of grain mass, strong SDE.

The coefficient of spatial determination $\left(r^{2}\right)$ was as follows: $\mathrm{BY}=\mathrm{f}(\mathrm{CM})(0.758), \mathrm{BY}=$ $\mathrm{f}(\mathrm{TPM})(0.739)$, and $\mathrm{BY}=\mathrm{f}(\mathrm{LW})(0.721)$, superior to 0.700 . On the other hand, their decreasing relation, analyzed by the magnitude of the $\left(A_{O}\right)$, was as follows: $B Y=f(L W)$ 


\begin{tabular}{|c|c|c|c|c|c|c|c|c|c|c|c|}
\hline \multirow[b]{2}{*}{ Production component $^{\mathrm{z}}$} & \multirow[b]{2}{*}{ Model $^{\mathrm{y}}$} & \multirow[b]{2}{*}{ Nugget $\mathrm{C}_{\mathrm{O}}$} & \multirow[b]{2}{*}{ Sill $\mathrm{C}_{\mathrm{O}}+\mathrm{C}$} & \multirow[b]{2}{*}{ Range $\mathrm{A}_{\mathrm{O}}(\mathrm{m})$} & \multirow[b]{2}{*}{$r^{2}$} & \multirow[b]{2}{*}{ SRS $^{x}$} & \multicolumn{2}{|c|}{$\mathrm{SDE}^{\mathrm{w}}$} & \multicolumn{3}{|c|}{ Cross-validation } \\
\hline & & & & & & & $\%$ & Class & $\mathrm{a}$ & $\mathrm{b}$ & $\mathrm{r}$ \\
\hline$\overline{\mathrm{BY}}$ & Exp & $3.86 \times 10^{6}$ & $7.72 \times 10^{6}$ & 12.6 & 0.71 & $1.63 \times 10^{10}$ & 50.0 & Moderate & 7367.8 & 0.60 & 0.35 \\
\hline TPM & Exp & 11.40 & 47.70 & 7.3 & 0.44 & 244.00 & 76.1 & Strong & 19.46 & 0.76 & 0.36 \\
\hline NL & Exp & 0.18 & 0.76 & 5.2 & 0.57 & 0.04 & 76.3 & Strong & -1.31 & 1.16 & 0.49 \\
\hline FTL & Sph & 7.00 & 15.00 & 9.0 & 0.71 & 12.70 & 53.3 & Moderate & 2.35 & 0.97 & 0.52 \\
\hline LL & Gau & 16.00 & 39.00 & 17.0 & 0.83 & 176.00 & 59.0 & Moderate & 2.00 & 0.98 & 0.68 \\
\hline LW & Sph & 2.00 & 4.70 & 20.0 & 0.79 & 1.46 & 57.4 & Moderate & -0.14 & 1.01 & 0.62 \\
\hline PD & Gau & 0.47 & 0.94 & 4.0 & 0.77 & 0.02 & 50.0 & Moderate & 0.67 & 0.94 & 0.46 \\
\hline SWM & Gau & 15.30 & 35.50 & 13.7 & 0.78 & 102.00 & 56.9 & Moderate & 0.58 & 0.99 & 0.63 \\
\hline SDM & Exp & 0.51 & 2.13 & 6.0 & 0.52 & 0.13 & 76.1 & Strong & 5.08 & 0.58 & 0.28 \\
\hline NCB & Pnf & 0.52 & 0.52 & - & - & - & - & - & - & - & - \\
\hline $\mathrm{CM}$ & Gau & 0.06 & 0.08 & 25.0 & 0.91 & $7.78 \times 10^{-5}$ & 30.5 & Moderate & 0.58 & 0.82 & 0.31 \\
\hline RDM & Pnf & 0.05 & 0.05 & - & - & - & - & - & - & - & - \\
\hline IRR & Sph & 208.00 & 595.00 & 14.3 & 0.50 & $5.81 \times 10^{4}$ & 65.0 & Moderate & -6.74 & 1.04 & 0.67 \\
\hline
\end{tabular}

${ }_{\mathrm{z}} \mathrm{BY}=$ garlic bulb yield $\left(\mathrm{kg} \cdot \mathrm{ha}^{-1}\right) ; \mathrm{TPM}=$ total plant mass $(\mathrm{g}) ; \mathrm{NL}=$ number of leaves (units); FTL = floral tassel length $(\mathrm{cm}) ; \mathrm{LL}=$ leaf length $(\mathrm{cm}) ; \mathrm{LW}=$ leaf width $(\mathrm{mm}) ; \mathrm{PD}=$ pseudostem diameter $(\mathrm{mm}) ; \mathrm{SWM}=$ shoot wet mass $(\mathrm{g}) ; \mathrm{SDM}=$ shoot dry mass $(\mathrm{g}) ; \mathrm{NCB}=$ number of cloves per bulb (units); $\mathrm{CM}=\mathrm{clove}$ mass (g); RDM = root dry mass (g); and external component interference, irrigation (IRR) with restriction applied in the bulb formation (mm).

${ }^{\mathrm{y}} \mathrm{Sph}=$ spherical; Exp = exponential; $\mathrm{Pnf}=$ pure nugget effect; Gau = gaussian

${ }^{\mathrm{x}} \mathrm{SRS}=$ sum of the residue square.

${ }^{\mathrm{w}} \mathrm{SDE}=$ spatial dependence evaluation.

Table 2. Estimated parameters for the cross-semivariogram of the garlic crop production components.

\begin{tabular}{|c|c|c|c|c|c|c|c|c|}
\hline \multirow{2}{*}{$\begin{array}{l}\text { Production } \\
\text { component }^{2}\end{array}$} & \multirow[b]{2}{*}{ Model $^{y}$} & \multirow[b]{2}{*}{ Nugget $C_{O}$} & \multirow[b]{2}{*}{ Sill $\mathrm{C}_{\mathrm{O}}+\mathrm{C}$} & \multirow[b]{2}{*}{ Range $A_{O}(m)$} & \multirow[b]{2}{*}{$r^{2}$} & \multirow[b]{2}{*}{$\mathrm{SRS}^{\mathrm{x}}$} & \multicolumn{2}{|c|}{$\mathrm{SDE}^{\mathrm{w}}$} \\
\hline & & & & & & & $\%$ & Class \\
\hline$\overline{B Y}=f(T P M)$ & Gau & $2.6 \times 10^{3}$ & $3,953.0$ & 21.0 & 0.739 & $7.0 \times 10^{5}$ & 33.3 & Moderate \\
\hline$B Y=f(L W)$ & Sph & $6.3 \times 10^{2}$ & 634.0 & 33.6 & 0.721 & $4.7 \times 10^{4}$ & 59.8 & Moderate \\
\hline$B Y=f(C M)$ & Gau & $1.9 \times 10^{2}$ & 198.0 & 19.0 & 0.758 & $1.3 \times 10^{3}$ & 35.4 & Moderate \\
\hline
\end{tabular}

(33.6) $\mathrm{m} ; \mathrm{BY}=\mathrm{f}(\mathrm{TPM})(21.0) \mathrm{m}$, and BY $=$ $\mathrm{f}(\mathrm{CM})(19.0) \mathrm{m}$. Thus, there was a significant linear correlation between BY and the other production components of the garlic crop, with satisfactory semivariographic adjustments. Therefore, it can be inferred, for example, that the CM was a good indicator of garlic BY when used for yield estimation in sandy soils.

\section{Conclusions}

The garlic BY and production components presented spatial dependence.

The spatial correlation between garlic BY and TPM, LW, and CM showed a moderate spatial dependence.

\section{Literature Cited}

Bessa, A.T.M., W.D.A.R. Lopes, M.D.P.O. da Silva, M.F.P.D. Lima, P.R.H.D. Oliveira, and M.Z.D. Negreiros. 2017. Caracterização físicoquímica de alho 'BRS Hozan' e 'Roxo Pérola de Caçador' em função do tempo de armazenamento. Rev. Colomb. Cienc. Hortic. 11(2): 368-377.

Brewster, J.L. 2008. Onions and other vegetable alliums $15^{\circ}$. Ed. CABI. Horticulture Research International, Wellesbourne, UK.

Cambardella, C.A., T.B. Moorman, J.M. Novak, T.B. Parkin, D.L. Karlen, R.F. Turco, and A.E. Konopka. 1994. Field scale variability of soil properties in Central Iowa soils. Soil Sci. Soc. Amer. J. 58(5):1501-1511.

Empresa Brasileira de Pesquisa Agropecuária EMBRAPA. 2018. Sistema brasileiro de classificação de solos. Brasília, DF: Embrapa.

IBGE - Instituto Brasileiro de Geografia e Estatística. Levantamento Sistemático da Produção Agrícola- LSPA. Novembro 2018. Brasília. Dec. 12, 2018. <https://www.ibge.gov.br/ estatisticas-novoportal/economicas/agricultura $>$.

Ferraz, G.A.S., F.M. Silva, L.C.C. Carvalho, M.C. Alves, and B.C. Franco. 2012. Variabilidade espacial e temporal do fósforo, potássio e da produtividade de uma lavoura cafeeira. Eng. Agr. 32(1):140-150.
Marouelli, W.A., M.B. Braga, M.A. Lucini, and F.V Resende. 2014. Circular Técnica 136: Irrigação na cultura do alho. Ministério da Agricultura, Pecuária e Abastecimento. Embrapa, BrasíliaDF.

Montanari, R., M.P. Carvalho, M.C.M.T. Filho, and F.C. Dalchiavon. 2013. Produção de matéria seca da braquiária de acordo com os atributos químicos de um Latossolo em Selvíria, Mato Grosso do Sul. Revista Ceres, Viçosa 60(6):772-784

Montanari, R., E. Panachuki, L.H. Lovera, A.R. Correa, I.S. Oliveira, H.A. Queiroz, and P.K. Tomaz. 2015. Variabilidade Espacial da Produtividade de Sorgo e de Atributos do Solo na Região do Ecótono Cerrado-Pantanal, MS Rev. Bras. Ciênc. Solo 39:385-396.

Oliveira, J.T., M. Passos, C.G. Roque, F.H.R. Baio, K.M. Kamimura, I.S. Ribeiro, and P.E. Teodoro. 2018. Space variability of phenological indicators of common bean crop. Biosci. J. 34(2): $1-8$.

Pimentel-Gomes, F.P. and C.H. Garcia. 2002. Estatística aplicada a experimentos agronômicos e florestais. FEALQ, Piracicaba, Brazil.

Resende, G.M. 1997. Desempenho de cultivares de alho no Norte de Minas Gerais. Hortic. Bras. 15:127-130.

Shapiro, S.S. and M.B. Wilk. 1965. An analysis of variance test for normality: Complete samples. Biometrika, London 52:591-611.

Trangmar, B.B., R.S. Yost, and G. Uehara. 1985. Application of geostatistics to spatial studies of soil properties. Adv. Agron. 38:45-94.

Viana, J.P.G., C.J. Pires, J.B. Pinheiro, S.E.S Valente, A.C.A. Lopes, and R.L.F. Gomes. 2016. Divergência genética em germoplasma de alho. Cienc. Rural 46(2):203-209. 
Supplemental Table 1. Descriptive statistics for garlic crop production components.

\begin{tabular}{|c|c|c|c|c|c|c|c|c|c|}
\hline Production component & Avg & Minimum & Maximum & SD & $\mathrm{CV}$ & Kurtosis & Asymmetry & $\operatorname{Pr}>F$ & FD \\
\hline$\overline{\mathrm{BY}}$ & 10,351 & 8,370 & 12,518 & 840 & 8.12 & -0.11 & -0.10 & 0.6587 & $\mathrm{NO}$ \\
\hline TPM & 81.09 & 66.10 & 99.00 & 6.55 & 8.08 & 0.07 & 0.05 & 0.6919 & $\mathrm{NO}$ \\
\hline NL & 8.28 & 6.33 & 10.50 & 0.88 & 10.62 & -0.35 & 0.02 & 0.6683 & $\mathrm{NO}$ \\
\hline FTL & 91.47 & 82.00 & 101.83 & 3.61 & 3.95 & 0.34 & 0.30 & 0.7137 & $\mathrm{NO}$ \\
\hline LL & 94.13 & 80.83 & 108.17 & 5.71 & 6.07 & -0.19 & 0.20 & 0.8068 & $\mathrm{NO}$ \\
\hline LW & 12.05 & 7.87 & 17.09 & 1.98 & 16.40 & -0.47 & 0.43 & 0.0423 & $\mathrm{TN}$ \\
\hline PD & 11.81 & 9.53 & 14.50 & 0.96 & 8.12 & -0.20 & 0.18 & 0.9815 & $\mathrm{NO}$ \\
\hline SWM & 38.07 & 25.67 & 49.33 & 5.37 & 14.11 & -0.77 & -0.10 & 0.4264 & $\mathrm{NO}$ \\
\hline SDM & 12.17 & 9.17 & 16.00 & 1.41 & 11.62 & -0.42 & 0.06 & 0.7159 & $\mathrm{NO}$ \\
\hline NCB & 13.57 & 11.33 & 15.00 & 0.72 & 5.33 & 0.30 & -0.40 & 0.0956 & $\mathrm{NO}$ \\
\hline $\mathrm{CM}$ & 3.15 & 2.53 & 3.77 & 0.27 & 8.50 & -0.60 & -0.11 & 0.6641 & $\mathrm{NO}$ \\
\hline RDM & 1.82 & 1.20 & 2.50 & 0.23 & 12.71 & 0.82 & -0.08 & 0.0923 & $\mathrm{NO}$ \\
\hline IRR & 194.91 & 129.40 & 225.68 & 22.40 & 11.49 & 1.05 & -1.34 & $<0.0000$ & ID \\
\hline
\end{tabular}

$\mathrm{BY}=$ garlic bulb yield $\left(\mathrm{kg} \cdot \mathrm{ha}^{-1}\right) ; \mathrm{TPM}=$ total plant mass $(\mathrm{g}) ; \mathrm{NL}=$ number of leaves (units); FTL = floral tassel length $(\mathrm{cm}) ; \mathrm{LL}=$ leaf length $(\mathrm{cm}) ; \mathrm{LW}=$ leaf

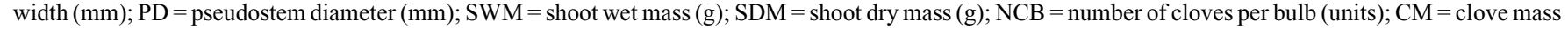

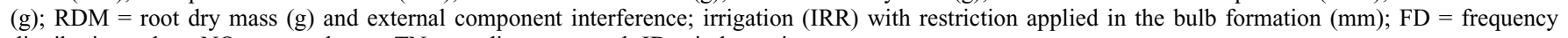
distribution, where $\mathrm{NO}=$ normal type; $\mathrm{TN}=$ tending to normal; ID = indeterminate.
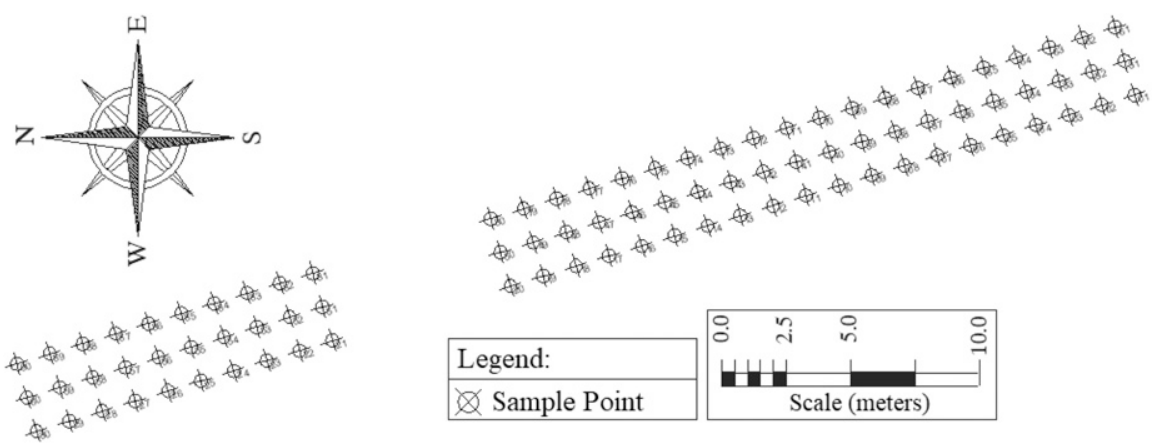

Supplemental Fig. 1. Detail of the sampling grid performed in the irrigation and drainage area of the Federal University of Viçosa, in Viçosa, Minas Gerais, Brazil, cultivated with garlic.
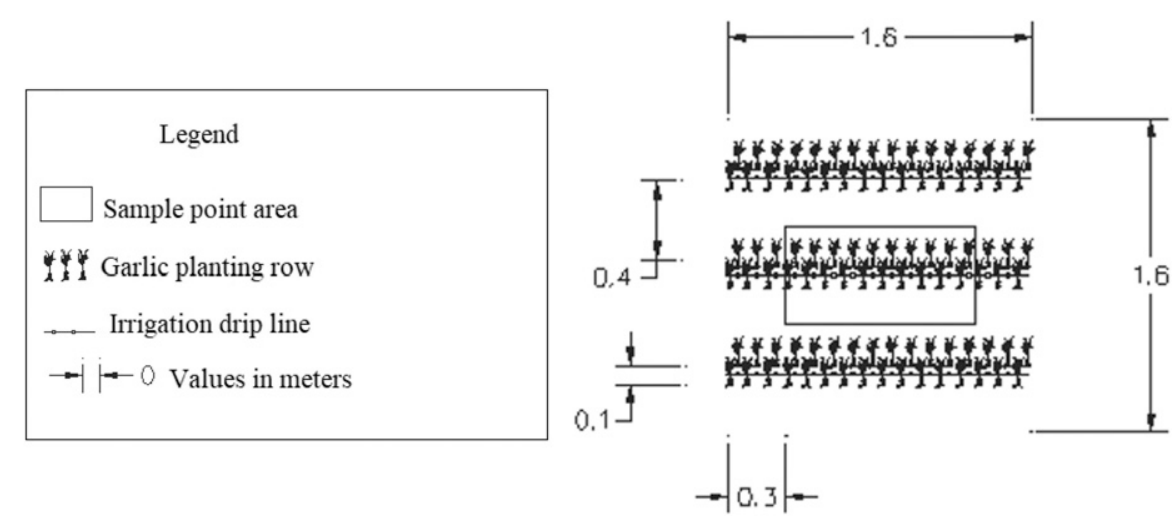

Supplemental Fig. 2. Detail of the garlic planting plot and representation of a sampling point (useful area). 

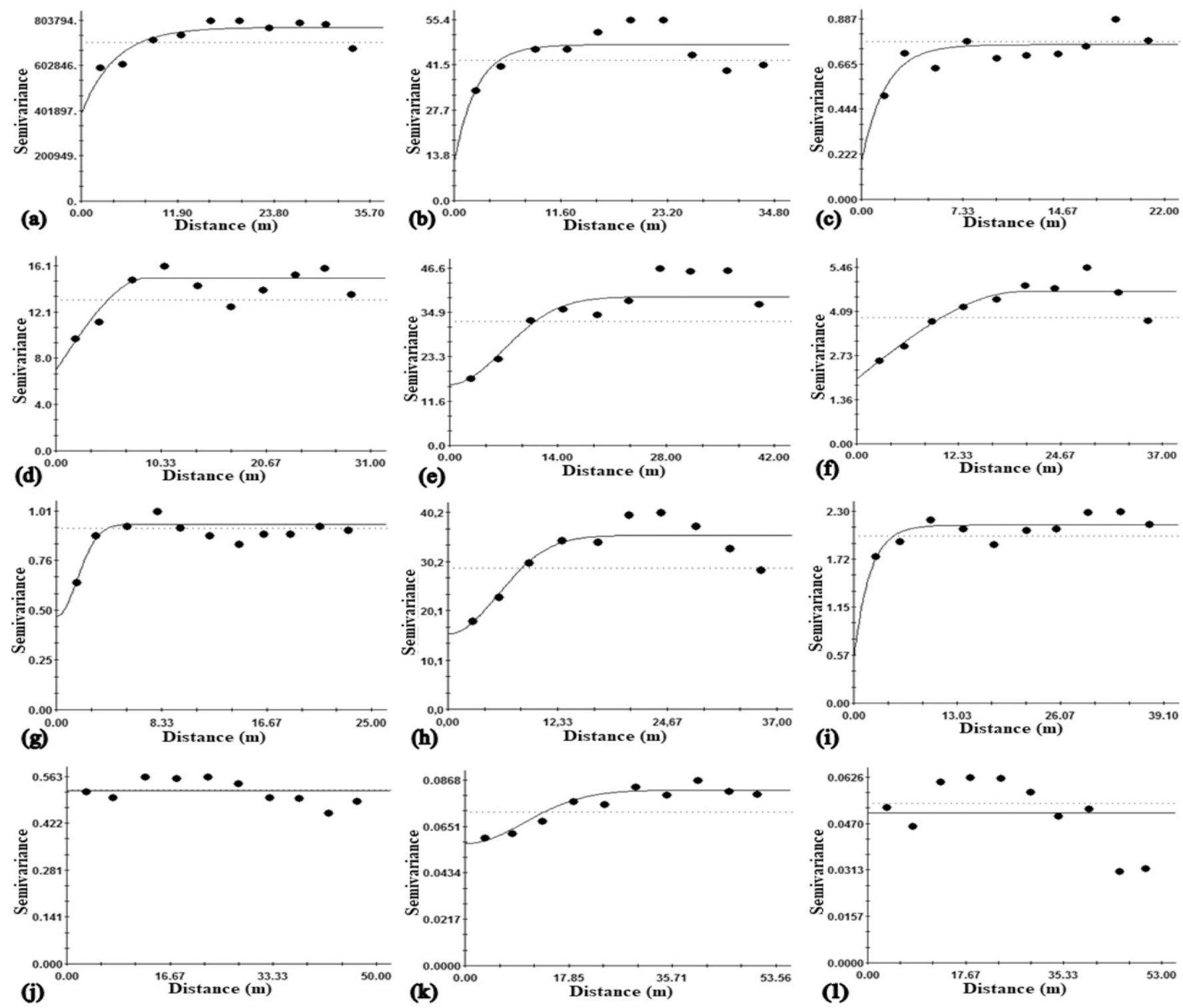

(i)
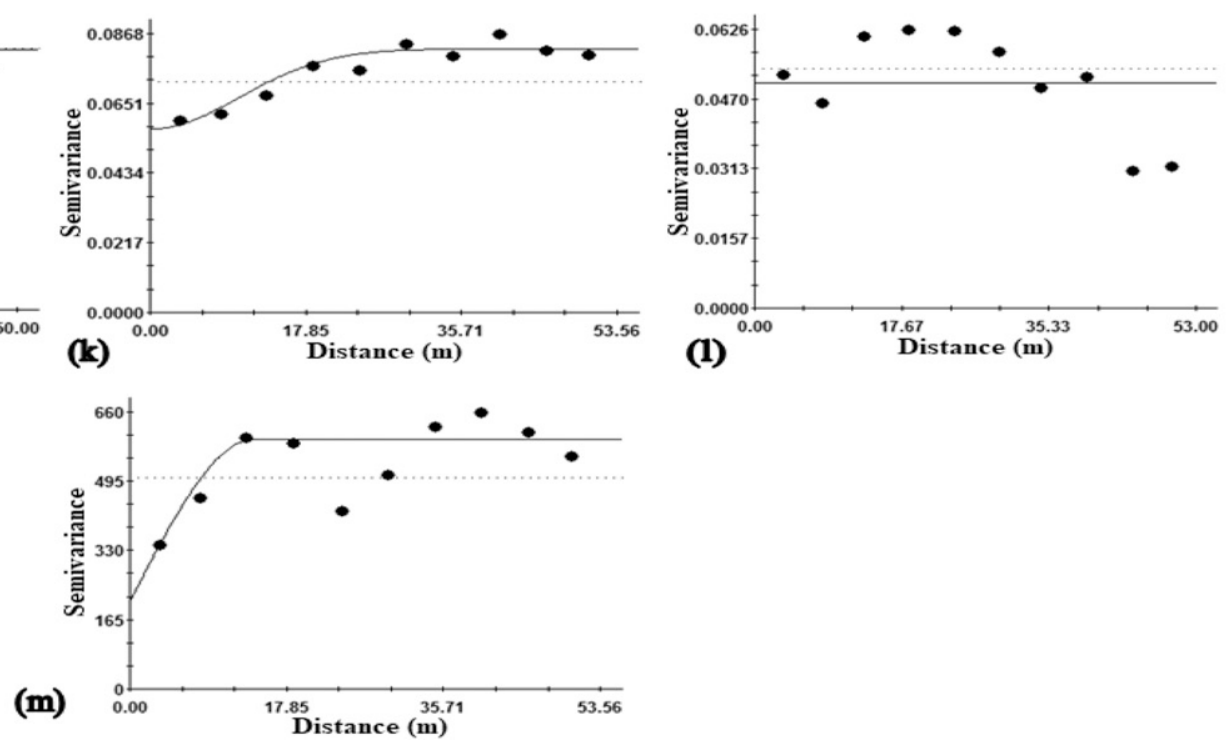

Supplemental Fig. 3. Semivariograms of the garlic production components, where (A) garlic bulb yield (BY) in $\mathrm{kg} \cdot \mathrm{ha}^{-1},(\mathbf{B})$ total plant mass (TPM) in grams, (C) number of leaves (NL), (D) floral tassel length $(\mathrm{FTL})$ in $\mathrm{cm},(\mathbf{E})$ leaf length $(\mathrm{LL})$ in $\mathrm{cm},(\mathbf{F})$ leaf width (LW) in mm, (G) pseudostem diameter (PD) in mm, (H) shoot wet mass (SWM) in grams, $(\mathbf{I})$ shoot dry mass (SDM) in grams, $(\mathbf{J})$ number of cloves per bulb (NCB), (K) clove mass $(\mathrm{CM})$ in grams, (L) root dry mass $(\mathrm{RDM})$ in grams, and (M) irrigation (IRR), with restriction applied in the bulb formation (mm). 